\title{
O documentário contemporâneo e os limites da realidade
}

\author{
Jennifer Jane Serra*
}

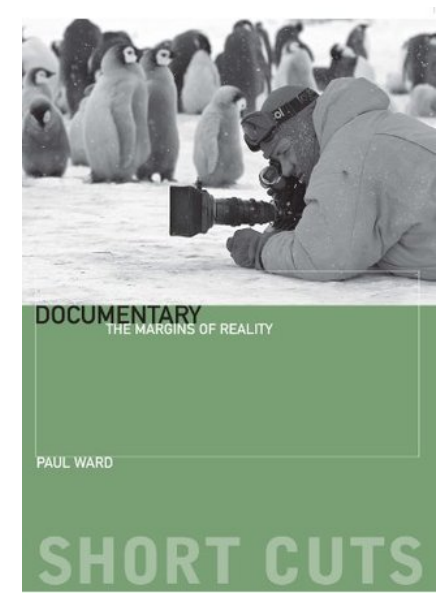

Ward, Paul (2005). Documentary: the margins of reality. London: Wallflower Press, ISBN-10: 1904764592, ISBN-13: 978-1904764595.

A produção de documentários híbridos cresceu significativamente nas últimas décadas, acompanhada de estudos e publicações que buscaram mensurar a dimensão desse desenvolvimento e analisar as singularidades do cinema documentário contemporâneo. O livro do pesquisador britânico Paul Ward, professor da Universidade de Artes de Bournemouth, Documentary: the margins of reality, ainda sem tradução para o português, apresenta-se como uma contribuição a esse contexto, fornecendo reflexões para a compreensão das novas formas que o documentário assumiu nos últimos anos. Seu foco de análise é um conjunto de produções que extrapolam as convenções mais estabelecidas do cinema documentário devido à miscigenação com formatos tradicionalmente dissociados a este, como a comédia, a ficção e a animação. Passada mais de uma década de sua publicação, em 2005, o livro traz estudos de filmes que aproximam-se de obras mais recentes e de temas que não foram ainda amplamente analisados, como a relação entre o humor e o compromisso ético do discurso documentário, mantendo sua atualidade e relevância.

* Universidade Estadual de Campinas - UNICAMP, Instituto de Artes, Centro Audiovisual de São Bernardo do Campo. 13083-970, Campinas, São Paulo, Brasil. E-mail: jennifer.jserra@gmail.com 
Além de trabalhar com produções que estendem os limites da representação da realidade, Ward retoma as ideias centrais no estudo do cinema documentário valendo-se de autores consagrados do campo, como Noël Carroll, Carl Plantiga, Brian Winston, Bill Nichols, Michael Renov, Stella Bruzzi, Dai Vaughan, entre outros. No primeiro capítulo, essa bibliografia é revisitada em brevidade para reestabelecer as especificidades do discurso documentário como sua oposição com a ficção, ou, como o autor coloca, "a tensão central que constitui todos os debates sobre o documentário: a relação entre realidade e artificialidade". A natureza construída do documentário é um ponto ressaltado por Ward que serve de contraponto ao senso comum que o toma como um formato objetivo e transparente e que por isso estaria distante de formatos tidos como subjetivos, como a ficção e a animação.

Nos capítulos seguintes, a distinção entre ficção e não ficção é posta em análise de maneira mais profunda a partir do exame de produções nas quais as fronteiras desses dois campos parecem indefinidas, como filmes documentários que usam encenação, reality shows, ou filmes sobre histórias reais que apresentam o uso de encenação executada por pessoas que viveram essas histórias ou com o uso do testemunho gravado dessas pessoas. O exemplo mais significativo analisado por Ward corresponde ao conjunto de filmes que tratam da vida de Aileen Wuornos, a estadunidense que se tornou notória por assassinar diversos homens e por isso condenada à morte. Ward compara dois documentários realizados pelo mesmo diretor, Nick Broomfield, Aileen Wuornos: The Selling of a Serial Killer (Nick Broomfield, 1992) e Aileen: Life and Death of a Serial Killer (Nick Broomfield, 2003) e dois filmes de ficção que tematizaram o caso: The Aieleen Wuornos Story (Peter Levin, 1992) e Monster (Patty Jenkins, 2003).

Segundo Ward, enquanto os filmes ficcionais se valem da premissa "história real" para sustentar a legitimidade de suas representações fictícias, os documentários privilegiam o desenvolvimento de uma trama em detrimento de um discurso mais imparcial, incluindo o recurso à narrativa em primeira pessoa usado por Broomfield, que se transforma em uma das testemunhas no julgamento de Wuornos. Mais do que isso, as duas formas de abordagem competem na apresentação do que seria a versão "verdadeira" de Aileen Wuornos e atuaram, junto com uma série de produções televisivas, na transformação de Wuornos em personagem de uma realidade midiática que se torna indistinguível da ficção em diferentes níveis. Trabalhando também com os casos de reconstituições e encenações em documentários com temas históricos, Ward aponta o potencial da performance para retratar a memória de eventos passados e como esses recursos podem amplificar o entendimento de tensões e questões subli- 
minares presentes no contexto desses eventos, para além de apenas "mostrar o que aconteceu".

Uma das contribuições mais significativas do livro diz respeito à relação entre o documentário e os campos da comédia e da animação. No primeiro caso, valendo-se de exemplos de falsos documentários, como a produção australiana The Wonderful World of Dogs (Mark Lewis, 1990) e a sitcom britânica The Office (Ricky Gervais, Stephen Merchant, 2001; 2003), Ward examina como no falso documentário a construção do texto humorístico se baseia na sátira, ironia ou paródia de convenções formais do filme documentário. Para que documentário e comédia se mesclem nessas produções é preciso que o público reconheça as marcas do texto original, do documentário, e o processo de transformação que a obra opera. A questão que emerge como central na análise de Ward sobre o hibridismo entre documentário e comédia é a contradição resultante da combinação de um discurso que se pretende objetivo e sério, ou, como propõe Bill Nichols, um discurso de sobriedade, tal qual o documentário mais tradicional, e outro que se apresenta como subjetivo e jocoso, como o da comédia. Para Ward, o público desempenha um papel fundamental no reconhecimento da zombaria, no caso das produções que parodiam esse formato como o falso documentário, e do uso do humor como uma estratégia possível para um discurso audiovisual comprometido com a realidade.

No último capítulo, Ward analisa o filme híbrido de documentário e animação: o documentário animado. O autor destaca a longa tradição de filmes de animação engajados em oferecer asserções sobre o mundo histórico, como, por exemplo, as animações educativas, os filmes de propaganda política, como Victory Through Air Power (Frank Thomas et al., 1943), do estúdio Disney, as animações da companhia britânica GPo Film Unit, como Trade Tattoo (Len Lye, 1937), produzidas em paralelo aos documentários, e o trabalho de animadoras que abordaram questões de gênero, como Joanna Quinn, Caroline Leaf, Ruth Lingford, entre outras. Apresentando as categorias de documentários animados propostas pelo teórico Paul Wells, Ward analisa filmes de curta-metragem como Leona Alone (Rani Khanna, 2004), What's Blood Got To Do With It? (Andy Glynne, 2004) e A is for Autism (Tim Webb, 1992), entre outros, indicando questões que surgem do casamento entre animação e documentário. Uma dessas questões diz respeito ao que o autor chama de "animatedness", a propriedade da animação de ter sua natureza animada sempre evidente, por mais realista que sejam seus gráficos ou sua abordagem. Segundo o autor, essa evidência da intervenção do animador por trás das imagens animadas contrasta com o senso comum do documentário como sendo portador de um registro objetivo e transparente da realidade. 
Como propõe Ward, essa natureza contraditória do documentário animado pode oferecer um "caminho intensificado para entender o mundo social", através do conflito resultante de sabermos que estamos diante da fala de uma pessoa real, ouvindo o áudio de um depoimento gravado, e sabermos que a imagem foi construída e não captada por uma câmera. Isso desperta nossa reflexão sobre a representação construída pelo filme e sua adequação em relação ao que ela representa. Ward destaca também a contribuição do documentário animado para o cinema, em sua habilidade de "documentar o indocumentável", através da representação de estados mentais, sentimentos, sensações e da subjetividade de indivíduos. A série inglesa Animated Minds (Andy Glynne, 2003, 2008), por exemplo, trata de casos de distúrbios mentais através da tradução em imagens animadas do depoimento de pessoas portadoras dessas doenças. Em documentários animados, a animação permite ao espectador visualizar aquilo que no documentário tradicional permaneceria apenas no plano das palavras, nas falas, como coloca o autor. Segundo Ward, esse tipo de produção faz também emergir a importância do áudio para o filme documentário, pois nesses casos o áudio assume um protagonismo maior do que em documentários convencionais, produzidos apenas com imagens filmadas.

Documentary: the margins of reality apresenta-se, dessa maneira, como uma obra que introduz o leitor ao exame do documentário contemporâneo. Através de estudos de casos, o livro exibe reflexões sobre algumas das questões mais pertinentes sobre essa produção, como o domínio da abordagem subjetiva e a diluição entre as fronteiras dos campos cinematográficos. Nesse sentido, ao analisar o filme Tarnation (2003), a autobiografia de Jonathan Caouette, Ward destaca como o tipo de filme documentário surgido com maior força nesse início de milênio tem intenso caráter pessoal, com foco na exposição de si mesmo. Para Ward, a produção de documentários de caráter subjetivo, autocentrado e miscigenado é reflexo de um mundo que se organiza também dessa forma. Seu livro, portanto, pode ser considerado como uma contribuição para a compreensão também da realidade representada nesses filmes. 